\title{
HLA Class II Histocompatibility Antigen, DR Alpha Chain
}

National Cancer Institute

\section{Source}

National Cancer Institute. HLA Class II Histocompatibility Antigen, DR Alpha Chain. NCI Thesaurus. Code C101159.

HLA class II histocompatibility antigen, DR alpha chain (254 aa, $\sim 29 \mathrm{kDa}$ ) is encoded by the human HLA-DRA gene. This protein plays a role in the presentation of antigen for recognition by CD4 T-cells. 